\title{
UPAYA MENINGKATKAN KINERJA DENGAN PENDEKATAN APLIKASI BALANCED SCORECARD PADA PERGURUAN TINGGI SWASTA DI JAKARTA
}

\author{
Rebin Sumardi ${ }^{1}$, Suryono Efendi ${ }^{1}$ \\ ${ }^{1}$ Program Studi Ekonomi dan Bisnis, Universitas Nasional \\ email : rebin67@yahoo.co.id, suryono.efendi@yahoo.com
}

Korespondensi : rebin67@yahoo.co.id

\begin{abstract}
Every company in the current era of globalization is highly required to be able to show optimal and superior performance in order to compete internationally, not just globally. Company performance can succeed well when supported by resources that are able to produce and realize the vision and mission of the organization. Organizations that are supported by strong and competent human resources with high commitment can definitely produce optimal performance. Higher education as an organization engaged in educational services is also required to demonstrate the ability to manage consumers optimally through a planned and systematic process, so that they have a good performance in managing educational services through the implementation of good university tridharma. Organizational performance in Higher Education can be measured through the Kaplan Balanced Scorcard approach, where the measurement approach includes (1). financial perspective, (2). Consumer perspective, (3). Internal business perspective, (4). and perspectives on learning and growth. Through this approach National University Organizational performance can be measured by finding that through financial, consumer, and internal business approaches can show good performance, but the measurement of a learning and nursing perspective approach shows poor performance. From the results of the performance of the National University, the organization's performance generally shows success, but the learning and growth perspective still needs to be pursued with a variety of strategic breakthroughs, in order to succeed well in the future.
\end{abstract}

Keywords: organizational performance, balanced scorecard, financial perspective, consumer, internal processes, growth.

\begin{abstract}
Abstrak
Setiap Perusahaan dalam era globalisasi saat ini, sangat dituntut untuk dapat menunjukan kinerja yang optimal dan unggul agar dapat bersaing di dunia internasional, bukan hanya global. Kinerja Perusahaan dapat berhasil dengan baik manakala didukung dengan sumber daya yang mampu menghasilkan dan mewujudkan visi misi organisasinya. Organisasi yang didukung dengan SDM yang tangguh dan kompeten dan memiliki komitmen yang tinggi pasti dapat menghasilkan kinerja yang optimal. Perguruan Tinggi sebagai organisasi yang bergerak di jasa pendidikan juga dituntut dapat menunjukan kemampuan dalam meleyani konsumen dengan optimal melalui proses yang terencana dan sistematis, sehingga memiliki
\end{abstract}


kinerja yang baik demi melayani jasa pendidikan dengan penyelengaraan tridharma perguruan tinggi yang baik. Kinerja organisasi di Perguruan tinggi dapat diukur melelui pendekatan Balanced Scorcard dari Kaplan, dimana pendekatan pengukuran ini meliputi (1). perspektif keuangan, (2). Perspektif konsumen, (3). Perspektif bisnis internal, (4). dan perspekif pembelajaran dan pertumbuhan. Melalui pendekatan ini kinerja Organisasi Universitas Nasional dapat diukur dengan temuan bahwa melalui pendekatan secara financial, konsumen, dan bisnis internal dapat menunjukan kinerja baik, namun pengukuran pendekatan perspektif pembelajaran dan pertumbuhan menujukkan kinerja yang kurang baik. Dari hasil pengukuran kinerja Universitas Nasional, secara umum kinerja Organisasi menunjukkan keberhasilan, namun pada perspektif pembelajaran dan pertumbuhan masih perlu diupayakan dengan berbagai terobosan strategis, agar berhasil dengan baik di kemudian hari.

Kata kunci: kinerja organisasi, balanced scorecard, perspektif keuangan, konsumen, proses internal, pertumbuhan.

\section{PENDAHULUAN \\ Latar Belakang Masalah}

Persaingan di tataran Perguran Tinggi Swasta di Indonesia semakin ketat seiring dengan perkembangan Teknologi dan Informasi yang maju pesat. Tuntutan terhadap kesiapan pergurun tinggi dalam perannya sebagai agen perubahan ilmu pengetahuan dirasakan cukup strategis, mengingat pelopor perubahan adanya di pergururn tunggi baik di Perguruan Tinggi Negeri atau di Perguruan Tinggi Swasta. Pengukuran kinerja merupakan usaha yang dilakukan pihak manajemen untuk mengevaluasi hasil-hasil kegiatan yang telah dilaksanakan oleh masing-masing pusat pertanggung-jawaban yang dibandingkan dengan tolak ukur yang telah ditetapkan. Sistem pengukuran kinerja dalam manajemen bukan pada satu aspek keuangan, karena ada aspek-aspek lain yang perlu pengukuran dalam menjalankan fungsi-fungsi manajemen, pengukuran dan penilaian kinerja suatu lembaga pendidikan seharusnya didasarkan pada kemampuannya untuk mewujudkan visi dan misinya. Selain itu dalam penilaian pada suatu lembaga pendidikan harus dilakukan secara menyeluruh dan menggunakan alat ukur yang bisa mengukur seluruh kegiatan pelayanan yang dilakukan organisasi, karena kegiatannya bersifat jasa dan bukanlah mencari laba. Para ahli manajemen menemukan suatu pendekatan penilaian kinerja perusahaan yang dapat diadopsi pada organisasi nir-laba. Alat penilaian kinerja yang disebut balanced scorecard merupakan metode penilaian kinerja yang komprehensif. Metode ini menilai kinerja menggunakan seperangkat ukuran kinerja terpadu yang telah disusun berdasarkan visi dan strategi.

Pengertian Kinerja didefinisikan serangkaian perilaku pekerja yang memberikan kontribusi baik secara positif maupun negatif, pada penyelesaian pekerjaan organisasi, Colquit, LePine, dan Wesson, (2011) dalam Manajemen Kinerja Wibowo. Prestasi kerja adalah penampilan kerja secara kualitas dan kuantitas yang disuguhkan oleh seorang pegawai dalam melaksanakan tugasnya sesuai dengan tanggung jawab yang diberikan kepadanya. Pendapat yang sama juga dikemukakan oleh Amstrong dan Baron (1998) dalam Wibowo (2014), Manajemen 
Kinerja (2014) bahwa kinerja menunjukkan hasil pekerjaan yang mempunyai hubungan yang kuat dengan tujuan strategis organisasi, kepuasan konsumen dan memberikan kontribusi ekonomi.

Berdasarkan tiga teori di atas dapat disimpulkan bahwa kinerja merupakan hasil kerja yang dapat dicapai pegawai dalam suatu organisasi, sesuai dengan wewenang dan tanggung jawab yang diberikan organisasi dalam upaya mencapai visi, misi, dan tujuan organisasi bersangkutan secara legal, tidak melanggar hukum dan sesuai dengan moral maupun etika. Kinerja pegawai dapat dilihat dari segi kecakapan, keterampilan, pengetahuan dan kesungguhan pegawai yang bersangkutan. Kelangsungan hidup suatu oganisasi tergantung salah satu dari segi kecakapan, keterampilan, pengetahuan dan kesungguhan pegawai yang bersangkutan. Oleh karena itu, "Manager must devise some strategies which will improve the performance of the employees working." Manajer harus memikirkan beberapa strategi yang akan digunakan untuk meningkatkan kinerja para pekerja.

Hasil pengukuran kinerja organisasi biasanya akan berbanding lurus dengan kondisi keberhasilan di bidang tri dharma perguruan tinggi, semakin kinerjanya tinggi maka pelaksanaan tri dharma akan semakin baik. Adapun tiga bidang itu adalah pelaksanaan bidang pendidikan, penelitian, dan pengadian kepada masyarakat di organisasi Perguruan Tinggi. Jika pelaksanaan tridharma perguruan tinggi dinilai rendah, maka kinerja perguruan tinggi (organisasi) juga dinilai rendah.

\section{Pokok Masalah}

Berdasarkan latar belakang di atas, penulisan artikel ini merumuskan permasalahan sebagai berikut:

1. Bagaimana menyusun alat ukur yang valid dan reliable untuk mengukur kinerja dengan menggunakan pendekatan balanced scorecard?

2. Apakah pengukuran kinerja organisasi Universitas Nasional dengan menggunakan pendekatan balanced scorecard sudah tepat?

\section{METODE}

Pendekatan

Pendekatan yang digunakan dalam penulisan artikel ini menggunakan ballanced scorecard, yaitu untuk mengkulaifikasikan data keuangan, dan data pendukung lainnya.

\section{METODE PENELITIAN}

Metode penelitian yang digunakan adalah survai, yaitu dengan data kuantitatif maupun kwalitatif, dengan menggunakan kuesioner sebagai alat pengumpulan datanya.

\section{Populasi dan Sampel.}

Populasi dalam penelitian ini adalah civitas akademika yang berada di Universitas Nasional, baik mahasiswa, pegawai, dosen. Sedangkan teknik sampel 
berupa kinerja dalam bentuk kuantitatif yaitu data pimer di Biro Keuangan serta data kualitatif berupa data survai kepada mahasiswa.

\section{KAJIAN TEORI}

\section{Pengertian Manajemen Kinerja}

Terdapat beberapa pengertian Manajemen Kinerja sebagaimana dikemukakan oleh para ahli. Namun dari pengertian beberapa ahli dapat diambil yang cukup substansi dan mudah dicerna yaitu, Amstrong (2009) yang mengutip pendapat Briscoe dan Claus (2008) memberikan pengertian "Manajemen kinerja" sebagai suatu sistem melalui mana organisasi menetapkan tujuan kinerja, mempertimbangkan standar kinerja, memberikan dan mengevaluasi kerja, menyediakan umpan balik kinerja, mempertimbangkan kebutuhan pelatihan dan pengembangan dan membagikan penghargaan. Sementara De Nisi (2000) dalam Wibowo (2014) memberi pengertian manajemen kinerja adalah suatu rentang dari praktik organisasi yang terikat dalam meningkatkan kinerja dari target orang atau kelompok dengan tujuan akhir memperbaiki kinerja organisasi.

\section{Penilaian Kinerja}

Penilaian Kinerja Menurut Bernardin and Russel (2010) terdapat empat kriteria untuk menilai kinerja karyawan.

1. Quality yaitu tingkatan di mana proses atau penyesuaian pada cara yang ideal di dalam melakukan aktifitas atau memenuhi aktifitas yang sesuai harapan.

2. Quantity yaitu jumlah yang dihasilkan diwujudkan melalui nilai mata uang, jumlah unit, atau jumlah dari siklus aktifitas yang telah diselesaikan.

3. Timeliness yaitu tingkatan di mana aktifitas telah diselesaikan dengan waktu yang lebih cepat dari yang ditentukan dan memaksimalkan waktu yang ada untuk aktifitas lain.

4. Cost effectiveness yaitu tingkatan di mana penggunaan sumber daya perusahaan berupa manusia, keuangan, dan teknologi dimaksimalkan untuk mendapatkan hasil .

\section{Balanced Scorecard}

Balanced Scorecard merupakan konsep manajemen yang diperkenalkan Robert Kaplan tahun 1992, sebagai perkembangan dari konsep pengukuran kinerja (performance measurement) yang mengukur perusahaan. Robert Kaplan mempertajam konsep pengukuran kinerja dengan menentukan suatu pendekatan efektif yang seimbang (balanced) dalam mengukur kinerja strategi perusahaan. Pendekatan tersebut berdasarkan empat perspektif yaitu keuangan, pelanggan, proses bisnis internal dan pembelajaran dan pertumbuhan. Keempat perspektif ini menawarkan suatu keseimbangan antara tujuan jangka pendek dan jangka panjang, hasil yang diinginkan (Outcome) dan pemicu kinerja (performance drivers) dari hasil tersebut, dan tolok ukur yang keras dan lunak serta subjektif.

Untuk mengetahui lebih jauh mengenai Balanced Scorecard, berikut ini dikemukakan pengertian Balanced Scorecard menurut beberapa ahli, di 
antaranya: Amin Widjaja Tunggal, (2002) "Balanced Scorecard juga menunjukkan bagaimana perusahaan menyempurnakan prestasi keuangannya".

Sedangkan tujuan dan pengukuran dalam Balanced Scorecard bukan hanya penggabungan dari ukuran-ukuran keuangan dan non-keuangan yang ada, melainkan merupakan hasil dari suatu proses atas bawah (top-down) berdasarkan misi dan strategi dari suatu unit usaha, misi dan strategi tersebut harus diterjemahkan dalam tujuan dan pengukuran yang lebih nyata".

Balanced scorecard terdiri dari dua kata yaitu balanced dan scorecard. Scorecard artinya kartu skor, maksudnya adalah kartu skor yang akan digunakan untuk merencanakan skor yang diwujudkan di masa yang akan datang. Sedangkan balanced artinya berimbang, maksudnya adalah untuk mengukur kinerja seseorang atau organisasi diukur secara berimbang dari dua perspektif yaitu keuangan dan non keuangan, jangka pendek dan jangka panjang, intern dan ekstern (Mulyadi, 2005).

Pada awalnya, balanced scorecard ditujukan untuk memperbaiki sistem pengukuran kinerja eksekutif. Sebelum tahun 1990-an eksekutif hanya diukur kinerjanya dari aspek keuangan, akibatnya fokus perhatian dan usaha eksekutif lebih dicurahkan untuk mewujudkan kinerja keuangan dan kecenderungan mengabaikan kinerja non keuangan. Pada tahun 1990, Nolan Norton Institute, bagian riset kantor akuntan publik KPMG, mensponsori studi tentang "Mengukur Kinerja Organisasi Masa Depan". Studi ini didorong oleh kesadaran bahwa pada waktu itu ukuran kinerja keuangan yang digunakan oleh semua perusahaan untuk mengukur kinerja eksekutif tidak lagi memadai.

Balanced scorecard digunakan untuk menyeimbangkan usaha dan perhatian eksekutif ke kinerja keuangan dan non keuangan, serta kinerja jangka pendek dan kinerja jangka panjang. Hasil studi tersebut menyimpulkan bahwa untuk mengukur kinerja eksekutif masa depan, diperlukan ukuran yang komprehensif yang mencakup empat perspektif yaitu keuangan, pelanggan, proses bisnis internal, dan pembelajaran dan pertumbuhan. Ukuran ini disebut dengan balanced scorecard.

Balanced scorecard yang baik harus memenuhi beberapa kriteria antara lain sebagai berikut :

a. Dapat mendefinisikan tujuan strategi jangka panjang dari masing - masing perspektif (outcomes) dan mekanisme untuk mencapai tujuan tersebut (performance driver).

b. Setiap ukuran kinerja harus merupakan elemen dalam suatu hubungan sebab akibat (cause and effect relationship).

c. Terkait dengan keuangan, artinya strategi perbaikan seperti peningkatan kualitas, pemenuhan kepuasan pelanggan, atau inovasi yang dilakukan harus berdampak pada peningkatan pendapatan perusahaan.

Langkah-langkah balanced scorecard meliputi empat proses manajemen baru. Pendekatan ini mengkombinasikan antara tujuan strategi jangka panjang dengan peristiwa jangka pendek. Keempat proses tersebut menurut (Kaplan dan Norton, 1996) antara lain :

1) Menterjemahkan visi, misi dan strategi perusahaan.

Untuk menentukan ukuran kinerja, visi organisasi perlu dijabarkan dalam tujuan dan sasaran. Visi adalah gambaran kondisi yang akan diwujudkan 
oleh perusahaan di masa mendatang. Untuk mewujudkan kondisi yang digambarkan dalam visi, perusahaan perlu merumuskan strategi. Tujuan ini menjadi salah satu landasan bagi perumusan strategi untuk mewujudkannya. Dalam proses perencanaan strategik, tujuan ini kemudian dijabarkan ke dalam sasaran strategik dengan ukuran pencapaiannya.

2) Mengkomunisasikan dan mengaitkan berbagai tujuan dan ukuran strategis balanced scorecard.

Dapat dilakukan dengan cara memperlihatkan kepada tiap karyawan apa yang dilakukan perusahaan untuk mencapai apa yang menjadi keinginan para pemegang saham dan konsumen. Hal ini bertujuan untuk mencapai kinerja karyawan yang baik.

3) Merencanakan, menetapkan sasaran, menyelaraskan berbagai inisiatif rencana bisnis.

Memungkinkan organisasi mengintergrasikan antara rencana bisnis dan rencana keuangan mereka. Balanced scorecard sebagai dasar untuk mengalokasikan sumber daya dan mengatur mana yang lebih penting untuk diprioritaskan, akan menggerakan kearah tujuan jangka panjang perusahaan secara menyeluruh.

4) Meningkatkan Umpan Balik dan pembelajaran strategis

Proses keempat ini akan memberikan strategis learning kepada perusahaan. Dengan balanced scorecard sebagai pusat sistem perusahaan, maka perusahaan melakukan monitoring terhadap apa yang telah dihasilkan perusahaan dalam jangka pendek.

\section{Empat Perspektif Balanced Scorecard}

Balanced scorecard adalah konsep yang mengukur kinerja suatu organisasi dari empat perspektif, yaitu perspektif finansial, perspektif customer, perspektif proses bisnis internal, perspektif pertumbuhan dan pembelajaran. Konsep balanced scorecard ini pada dasarnya merupakan penerjemahaan strategi dan tujuan yang ingin dicapai oleh suatu perusahaan dalam jangka panjang, yang kemudian diukur dan dimonitoring secara berkelanjutan.

Menurut Kaplan dan Norton (1996), balanced scorecard memiliki empat perspektif, antara lain :

1. Perspektif Keuangan (Financial Perspective)

Balanced scorecard menggunakan tolok ukur kinerja keuangan, seperti laba bersih dan ROI (Return On Investment), karena tolok ukur tersebut secara umum digunakan dalam organisasi yang mencari keuntungan atau provit. Tolok ukur keuangan memberikan bahasa umum untuk menganalisis perusahaan. Orang-orang yang menyediakan dana untuk perusahaan, seperti lembaga keuangan dan pemegang saham, sangat mengandalkan tolok ukur kinerja keuangan dalam memutuskan hal yang berhubungan dengan dana.

Tolok ukur keuangan yang di design dengan baik dapat memberikan gambaran yang akurat untuk keberhasilan suatu organisasi. Tolok ukur keuangan adalah penting, akan tetapi tidak cukup untuk mengarahkan kinerja dalam menciptakan nilai (value). Tolok ukur non keuangan juga 
tidak memadai untuk menyatakan angka paling bawah (bottom line). Balanced scorecard mencari suatu keseimbangan dan tolok ukur kinerja yang multiple-baik keuangan maupun non keuangan untuk mengarahkan kinerja organisasional terhadap keberhasilan.

2. Perspektif Pelanggan (Customer Perspective)

Perspektif Pelanggan berfokus pada bagaimana organisasi memperhatikan bagaimana pelanggannya agar berhasil. Mengetahui palanggan dan harapan mereka tidaklah cukup, suatu organisasi juga harus memberikan insentif kepada manajer dan karyawan yang dapat memenuhi harapan pelanggan. Bill Mariot mengatakan "Take care of you employee and they take care of your customer". Perhatikan karyawan anda dan mereka akan memperhatikan pelanggan anda. Perusahaan antara lain menggunakan tolok ukur kinerja berikut, pada waktu mempertimbangkan perspektif pelanggan yaitu :
a. Kepuasan pelanggan (customer satisfaction)
b. Retensi pelanggan (customer retention)
c. Pangsa pasar (market share)
d. Pelanggan yang profitable

3. Perspektif Proses Bisnis Internal (Internal Business Process Perspective) Terdapat hubungan sebab akibat antara perspektif pembelajaran dan pertumbuhan dengan perspektif bisnis internal dan proses produksi. Karyawan yang melakukan pekerjaan merupakan sumber ide baru yang terbaik untuk proses usaha yang lebih baik. Hubungan pemasok adalah kritikal untuk keberhasilan, khususnya dalam usaha eceran dan perakitan manufacturing. Perusahaan tergantung pemasok mengirimkan barang dan jasa tepat pada waktunya, dengan harga yang rendah dan dengan mutu yang tinggi.Perusahaan dapat berhenti berproduksi apabila terjadi problema dengan pemasok. Pelanggan menilai barang dan jasa yang diterima dapat diandalkan dan tepat pada waktunya. Pemasok dapat memuaskan pelanggan apabila mereka memegang jumlah persediaan yang banyak untuk meyakinkan pelanggan bahwa barang - barang yang diminati tersedia ditangan. Akan tetapi biaya penanganan dan penyimpanan persediaan menjadi tinggi, dan kemungkinan mengalami keusangan persediaan. Untuk menghindari persediaan yang berlebihan, alternatif yang mungkin adalah membuat pemasok mengurangi throughput time. Throughput time adalah total waktu dari waktu pesanan diterima oleh perusahaan sampai dengan pelanggan menerima produk. Memperpendek throughput time dapat berguna apabila pelanggan menginginkan barang dan jasa segera mungkin.

4. Perspektif Pembelajaran dan Pertumbuhan (Learn and Growth / Infrastucture Perspective)

Untuk tujuan insentif, perspektif pembelajaran dan pertumbuhan berfokus pada kemampuan manusia. Manajer bertanggung jawab untuk mengembangkan kemampuan karyawan. Tolok ukur kunci untuk menilai kinerja manajer adalah kepuasan karyawan, retensi karyawan, dan produktivitas karyawan. Kepuasan karyawan mengakui bahwa moral karyawan adalah penting untuk memperbaiki produktivitas, mutu, kepuasan 
pelanggan, dan ketanggapan terhadap situasi. Manajer dapat mengukur kepuasan dengan mengirim survei, mewawancara karyawan, mengamati karyawan pada saat bekerja. Kepuasan karyawan mengakui bahwa karyawan yang mengembangkan modal intelektual khusus organisasi adalah merupakan aktiva non keuangan yang bernilai bagi perusahaan. Lagi pula adalah sangat mahal menemukan dan menerima orang yang berbakat untuk menggantikan orang yang meninggalkan perusahaan. Perputaran karyawan diukur dengan persentase orang yang keluar setiap tahun, hal ini merupakan tolok ukur umum untuk retensi.

\section{HASIL DAN PEMBAHASAN}

\section{Pengukuran Kinerja Organisasi Universitas Nasional dengan Pendekatan Balanced Scorecard.}

Berdasarkan teori Kaplan dan Norton (1996), balanced scorecard memiliki empat perspektif, maka Universitas Nasional sebagai lembaga Pendidikan juga dapat diukur kinerjanya dengan pendekatan balanced scorecard seperti pembahasan sebagai berikut :

\section{Perspektif Keuangan (Financial Perspective)}

Balanced scorecard menggunakan tolok ukur kinerja keuangan, seperti laba bersih dan ROI (Return On Investment), karena tolok ukur tersebut secara umum digunakan dalam organisasi yang mencari keuntungan atau provit. Tolok ukur keuangan memberikan bahasa umum untuk menganalisis perusahaan. Universitas Nasional dalam hal pengelolaan keuangan juga telah memiliki system sebagaimana berlaku kaidah-kaidah keuangan. Sebagai alat analisis dalam Balanced scorecard maka ditampilkan Laba bersih selama 2 tahun berturut-turut yakni Laba bersih 2015-2016, seperti pada tabel 1 dibawah ini.

Tabel 1. Laba Bersih Universitas Nasional Tahun 2015-2016

(Dalam Milyar Rupiah)

\begin{tabular}{|l|c|c|c|l|}
\hline Komponen & $\begin{array}{c}\text { Realisasi } \\
2015\end{array}$ & $\begin{array}{c}\text { Realisasi } \\
2016\end{array}$ & $\begin{array}{c}\text { Kenaikan } \\
(\%)\end{array}$ & $\begin{array}{l}\text { Ditargetkan } \\
\text { kenaikan }>10 \%\end{array}$ \\
\hline Pendapatan & 57,3 & 64,7 & 12,9 & Target terpenuhi \\
\hline By Pendidikan & 29,1 & 32,4 & 11,3 & Target terpenuhi \\
\hline By Lit \& Peng Mas & 5,8 & 6,5 & 12,1 & Target terpenuhi \\
\hline By Penunjang & 2,9 & 3,3 & 13,8 & Target terpenuhi \\
\hline $\begin{array}{l}\text { By Investasi } \\
\text { Pengembangan }\end{array}$ & 10.4 & 11,5 & 10,6 & Target terpenuhi \\
\hline Total Opersi & 48,2 & 53,7 & 11,8 & Target terpenuhi \\
\hline Laba bersih & 9,1 & 11,0 & 20,9 & Target terpenuhi \\
\hline
\end{tabular}

Berdasarkan tabel 1. tersebut diatas, terlihat bahwa kinerja keuangan Universitas Nasional menunjukan cukup baik, hal ini dapat dilihat dari total 
pendapatan tahun 2015 sebesar 57,3 M dan tahun 2016 Rp. 64,7 M dengan kenaikan $12,9 \%$, dimana kenaikan yang ditargetkan $10 \%$ sehingga melampaui target dan dinilai bagus.

Data total operasional dengan kenaikan $11,8 \%$ dinilai baik karena mencerminkan gap yang tidak terlalu jauh dengan pendapatan, dan dinilai realistis seiring dengn pelaksanaan aktivitas organisasi di Universias Nasional yang berjalan dengan baik. Informasi lain juga menunjukan daya serap anggaran biaya pendidikan, biaya penelitian dan pengabdian pada masyarakat serta biaya penunjang pengembangan SDM serta inventasi pengembangan fisik dinilai baik. Laba bersih sebesar Rp. 9,1 M pada tahun 2015, dan tahun 2016 mendaptkan laba bersih Rp. 11 $\mathrm{M}$, atau naik $20 \%$ merupakan prestasi perolehan yang cukup bagus.

Hal ini dapat dinilai bahwa kinerja Universitas Nasional dari sisi performance financial cukup bagus, terbukti bawa pendaptan dan belanja dapat berjalan dinamis, namun sebagai sebuah pencapaian visi dan misi termasuk berhasil karena masih dapat mencapai laba yang diatas target sebesar $10 \%$.

\section{Perspektif Pelanggan (Customer Perspective)}

Perspektif Pelanggan berfokus pada bagaimana Universitas Nasional memperhatikan bagaimana pelanggannya agar berhasil dalam hal ini adalah mahasiswa. Untuk mengetahui tingkat kepuasan pelanggan (customer satisfaction) maka Universitas mengadakan pengukuran dengan cara menyebarkan kepada mahasiswa tiap akhir semester untuk mengetahui tingkat kepuasan layanan kepada mereka. Dalam hal ini quis diberikan saat mahasiswa ingin melihat nilai dimana dalam prosedurnya selalu mengisi penilaian terhadap layanan kepada mahasiswa, baik saat pelayanan perkuliahan maupun administrasi akademik yang diberikan selama ini. Melalui sampel dengam mengamil sampel 200 mahasiswa yang akan lulus dan diwisuda, diberikan angket untuk mengisi tingkat kepuasan yang dirasakan selama kuliah di Unas. Hasil dari pengisian quis tersebut sebagaimana tersaji pada tabel 2 tingkat Kepuasan Mahasiswa terhadap pelayanan dan kinerja Universitas Nassional sebagai berikut :

Tabel 2. Kepuasan Mahasiswa selama periode 2015-2016

\begin{tabular}{|c|l|r|r|r|l|l|}
\hline Skor & Skala Penilaian & 2015 & 2016 & $\begin{array}{c}\% \\
\text { kenaikan }\end{array}$ & $\begin{array}{c}\% \\
\text { Target }\end{array}$ & Keterangan \\
\hline 5 & $\begin{array}{l}\text { Sangat } \\
\text { memuaskan }\end{array}$ & 58 & 63 & 10,96 & 5 & Baik \\
\hline 4 & Memuaskan & 82 & 85 & 3,6 & 5 & Baik \\
\hline 3 & $\begin{array}{l}\text { Cukup } \\
\text { memuaskan }\end{array}$ & 41 & 44 & 7,3 & 5 & Baik \\
\hline 2 & $\begin{array}{l}\text { Tidak } \\
\text { memuaskan }\end{array}$ & 19 & 8 & 137,5 & 5 & Sangat baik \\
\hline 1 & Sangat tidak & - & - & & - & - \\
\hline
\end{tabular}




\begin{tabular}{|l|l|l|l|l|l|l|}
\hline & memuaskan & & & & & \\
\hline & $\begin{array}{l}\text { Jumlah } \\
\text { Responden }\end{array}$ & 200 & 200 & & & \\
\hline
\end{tabular}

Dari tebel 2 diatas tentang tingkat kepuasan konsumen atau mahasiswa terhadap pelayanan akademik dilingkungan Universitas Naional menunjukan baik dan semakin meningkat pelayanannya. Mahasiswa merasa puas dengan tingkat pelayanan yang dirasakan selama mengikuti kuliah di Universitas Nasional. Selama periode 2015-2016 hampir semua kriteria mengalami kenaikan. Mahasiswa yang diminta mengisi kuesioner melalui aplikasi akademik sebelum melihat transkrip nilai dan mengisi Kartu Rencana Studi. Mahasiswa dimintai bagaimana pelayanan akademik yang telah diberikan oleh Universitas selama studi, dan mahasiswa menjawab terhadap berbagi aspek pelayanan dengan kriteria skala likert 5 tingkatan. Yaitu sangat memuaskan memberikan skor 5, memuaskan skor 4, Cukup memuaskan skor 3, tidak memuaskan skor 2, dan sangat tidak memuaskan skor 1 .

Dengan berpedoman hasil kuesioner tersebut, dapat menjadi modal pengukuran kinerja organisasi khususnya dilihat dari aspek konsumen mahasiswa cukup memenuhi harapan dan baik.

\section{Perspektif Proses Bisnis Internal}

Untuk meningkatkan perspektif proses bisnis pendidikan maka Universitas Nasional mematangkan dan menyiapkan sebuah pelayanan dan proses akademik agar sesuai dengan kebutuhan pelanggan. Untuk itu setiap dosen dan karyawan selalu siap melayani dengan sebaik-baiknya. Universitas telah melakukan upaya pelatihan dan pengembangan baik jangka pendek maupun jangka panjang. Pelatihan jangka pendek seperti melatih dan mengirimkan tenaga kependidikan ke berbagai pelatihan untuk melatih keterampilan dan menambah wawasan dalam menunjang kompetensi karyawan dalam proses pelayanan Universitas untuk memperpendek waktu pelayanan dan promosi kepada calon mahasiswa baru agar efektif dan efisien. Dosen juga demikian untuk meningkatkan kompetensi dikirimkan ke berbagai lembaga dalam rangka menambah keilmuan dan keterampilan melalui program pengembangan Universitas dalam bentuk kursus sampai studi lanjut jenjang S3.

Adapun pengukuran proses ini dapat dilihat pada tabel 3 berupa jumlah biaya pelatihan untuk promosi dengan perbandingan biaya jumlah perolehan mahasiswa baru selama 2 tahun 2015 - 2016, seperti tersaji dalam tabel 3 sebagai berikut :

Tabel 3. Biaya Promosi dan Hasil Penerimaan Mahasiswa Baru

\begin{tabular}{|l|c|c|c|l|}
\hline \multicolumn{1}{|c|}{ Komponen } & 2015 & 2016 & \% kenaikan & Kategori \\
\hline $\begin{array}{l}\text { Biaya pelatihan dan } \\
\text { promosi }\end{array}$ & Rp. 1,4 M & Rp.1,6 M & 14,28 & Baik \\
\hline $\begin{array}{l}\text { Jumlah Mahasiswa } \\
\text { baru }\end{array}$ & $3.072 \mathrm{mhs}$ & $3.817 \mathrm{mhs}$ & 24,25 & Sangat Baik \\
\hline
\end{tabular}


Dari tabel 3 tersebut diatas, terlihat bahwa biaya pelatihan dan promosi pada tahun 2015 sejumlah Rp.1,4 M dan naik pada tahun 2016 menjadi 1,6 M atau naik sebesar $14,28 \%$, dengan harapan naiknya biaya pelatihan dan biaya promosi ini akan menaikan jumlah mahasiswa baru ke Universitas Nasional. Terbukti kenaikan biaya pelatihan dan promosi ini membawa naiknya jumlah mahasiswa yang masuk Universitas pada tahun 2016 sebanyak 24,25\% dan ini merupakan kategori sangat bagus.

Ini dapat menjadi model dalam upaya organisasi khususnya Universitas yang mengaitkan biaya pelatihan dan promosi dengan jumlah konsumen yakni mahasiswa baru dapat terserap dengan baik. Walaupun banyak variabel soal kenaikan jumlah mahasiswa baru ke Universitas, namun perlu di teliti lebih lanjut.

\section{Perspektif Pembelajaran dan Pertumbuhan}

Untuk mengetahui kepuasan karyawan, retensi karyawan, dan produktivitas karyawan maka perlu dilakukan langkah-langkah dalam proses pembelajaran dan memperhatikan adanya pertumbuhan organisasi yang semakin dinamis. Kepuasan karyawan mengakui bahwa moral karyawan adalah penting untuk memperbaiki produktivitas, mutu, kepuasan pelanggan, dan ketanggapan terhadap situasi. Manajer dapat mengukur kepuasan dengan mengirim survei, mewawancara karyawan, mengamati karyawan pada saat bekerja. Untuk itu Universitas melakukan survei dan mengamati karyawan melalui angket untuk menilai kepuasan karyawan terhadap pendapatan dan insentif yang mereka terima serta beberapa jenjang karir yang dikembangkan oleh Universitas Nasional, sebagaimana terlihat dalam tabel 4 dibawah ini.

Tabel 4. Penilaian Kepuasan Pegawai atas Pendapatan, Insentif, dan Karir Kepegawaian Periode 2015-2016.

\begin{tabular}{|c|l|c|c|c|l|}
\hline Skor & Skala Penilaian & 2015 & 2016 & $\begin{array}{c}(\%) \\
\text { Naik /turun }\end{array}$ & Kategori \\
\hline 5 & Sangat memuaskan & 15 & 11 & 3,6 & Kurang baik \\
\hline 4 & Memuaskan & 27 & 25 & 8 & Kurang baik \\
\hline 3 & Cukup memuaskan & 41 & 44 & 9,6 & Baik \\
\hline 2 & Tidak memuaskan & 17 & 20 & 15 & Kurang baik \\
\hline 1 & Sangat tidak memuaskan & - & - & - & - \\
\hline & Jumlah & 100 & 100 & & \\
\hline
\end{tabular}

Berdasarkan table 4 diatas, terlihat bahwa tingkat kepuasan para pegawai (dosen dan karyawan) secara trendnya selama tahun 2015-2016 mengalami penurunan terhadap penilaian pendapatan, insentif, karir pembinaan di Universitas dan hal-hal lain menyangkut alat motivasi kepada pegawai. Penurunan kwalitas pelayanan pendapatan dan insentif ini dialami oleh responden dengan penurunan angka semula skor sangat memuaskan pada tahun 2015 berjumlah 15 orang, pada 
tahun 2016 menjadi hanya 11 orang. Begitu juga pada kategori memuaskan menurun dari 27 menjadi 25. Hal ini menunjukkan bahwa dalam memberikan pendapatan, insentif dan hak-hak lain masih perlu diperhatikan dalam usaha untuk mempertahankan pegawai yang berkualitas, demi terus menjaga kemajuan Universitas Nasional. Masalah renumerasi ini memang secara klasik jika ditanyakan kepada para pegawai hampir rata-rata menjawab belum puas. Hal ini terkait bahwa kebutuhan pegawai sebagai manusia selalu dinamis dan berkembang, sementara organisasi seperti Universitas adalah lembaga pendidikan yang tidak harus berorientasi mendapatkan keuntungan yang besar seperti organisasi bisnis pada umumnya.

Akan tetapi penurunan ini berlaih ke cukup memuaskan naik 3 dan tidak memuaskan naik 3 juga, sehingga beralihnya penilaian dari sangat memuaskan cenderung menjadi cukup memuaskan atau dengan kata lain menurun tingkat kepuasan terhadap kesejahteraan yang mereka terima.

\section{SIMPULAN DAN REKOMENDASI Simpulan}

Berdasarkan hasil uraian analisis, pengukuran kinerja dosen dengan pendekatan balanced scorecard di Universitas Nasional dapat disimpulkan sebagai berikut:

a. Instrumen yang disusun masih terlalu sederhana, karena masih kurangnya literatur yang digunakan sebagai pembuatan instrumen tersebut, sehingga belum mengukur secara keseluruhan dalam menentukan tinggi rendahnya kinerja organisasi Universitas Nasional.

b. Kinerja organisasi Universitas Nasional dilihat dari perspektif keuangan cukup bagus, dengan telah optimalnya pemanfaatan anggaran tentu dengan menyesuaikan pendapatan Universitas dalam melaksankan program kegiatan tridharma perguruan tinggi, dan pencapaian laba usaha yang cukup baik pada tahun 2015-2016.

c. Kinerja organisasi dilihat dari perspektif pelanggan cukup baik, dengan terbukti hasil yang cukup memuaskan dalam melayani konsumen khususnya pelayanan perkuliahan dan akademik di lingkungan Universitas Nasional.

d. Kinerja organisasi dilihat dari perspektif proses bisnis internal juga menunjukkan adanya pengelolaan dan proses yang baik, dengan dibuktikannya pemanfaatan sumberdaya internal untuk berupaya memperolah kepercayaan lebih baik dari masyarakat sehingga mahasiswa baru terus bertambah selama 2 tahun terakhir.

e. Kinerja organisasi dari sisi perspektif pertumbuhan dan pembelajaran dinilai tidak terlalu baik dengan hasil evaluasi ke dalam kepada pegawai dimana faktor kompensasi dan hal-hal kesejahteraan belum sesuai harapan mereka.

f. Secara keseluruhan kinerja Universitas dengan perspektif pendekatan Balance Scorecard ini bisa mengukur dan menggambarkan potret kinerja yang cukup baik selama periode pengamatan. 


\section{Rekomendasi}

a. Untuk meningkatkan kinerja organisasi maka faktor-faktor penting seperti kesejahteraan pegawai harus diperhatikan dan mendapatkan perhatian serius, dengan memberikan kesejahteraan secara layak dan dapat memenuhi kebutuhan hidup pegawai Universitas Nasional.

b. Faktor-faktor untuk meningkatkan kinerja organisasi harus dibenahi secara simultan sehingga dapat menunjang kemajuan organisasi.

\section{DAFTAR PUSTAKA}

Armstrong, M. and Baron, A. (1998). Performance Management. London: Institute of Personnel and Developmen.

Bernardin, H.J and Russel, J.E.A. (2000). Human Resource Managemen. Singapore: McGraw-Hill.

Briscoe, D and Claus, L. (2008). Employee Performance Management: Policies and Practices in Multinasional Enterprises, in Varma et al(eds) Performance Managemen Systems: A Global Perspective. London: Routledge.

Colquitt, Jason A. Le Pine, Jeffrery A.Wesson, Michael J. (2011). Organizational Improving and Commitment in the Workplace. New York; The Mcgraw-Hill Companies, Inc.

Data Laporan Laba/Rugi Unas 2015 /2016.

De Nisi, A.S. (2000). Performance Appraisal and Performance Management: A multilevel analysis. In K.K. Klein \& S. Kozlowski (Eds), Multilevel Theory research and method in organizations. San Francisco: Jossey-Bass.

Hasil Kinerja Universitas Nasional, 2016.

Mulyadi. (2005). Balanced Scorecard. Jogjakarta: Salemba Empat.

Norton, David P., Kaplan, Robert S. (1996). The Balanced Scorecard: Translating Strategy Into Action. HBS Press.

Tunggal, Amin Wijaya. (2002). Internal Auditing (Suatu Pengantar). Jakarta: Harvarindo.

Wibowo. (2014). Manajemen Kinerja, Edisi Keempat. Akarta: Rajawali Pers. 